\title{
Menopause Matters
}

\section{Susan Quilliam}

Writer, Broadcaster, Consultant and Trainer, Cambridge, UK

Correspondence to Ms Susan Quilliam, Cambridge, UK; susan@susanquilliam.com; http://www.susanquilliam.com

Received 21 August 2014 Accepted 21 August 2014

\section{CrossMark}

To cite: Quilliam S. J Fam Plann Reprod Health Care 2014;40:306-307.

\section{WHO ARE YOU?}

Menopause Matters provides patients with information, support and advice about the menopause and its treatment options via our website (http://www. menopausematters.co.uk), our print magazine, our downloadable leaflets and through e-mail consultation. We also provide website cards and magazines for GP surgeries, to be available as patient support.

\section{HOW AND WHY DID YOU BEGIN?}

Heather Currie, an associate specialist gynaecologist, former Associate Editor of this Journal and currently (2014) Honorary Secretary and Chair Elect of the British Menopause Society, initially realised that women have a huge need for accurate, independent information and support about the menopause. Assisted by a number of Scottish-based clinicians, she founded Menopause Matters in 2001. The website was launched in 2002 and the magazine in 2005.

\section{WHO IS INVOLVED?}

Heather Currie, founder and managing director, plus a webmaster, a social media manager, a magazine editor, an advertising manager and a finance director.

\section{WHO ARE YOUR USERS AND WHAT ARE THEIR NEEDS?}

Our users are any women experiencing the menopause who have need of our support. The main problems about which women contact us are: distressing symptoms, concern about the risks of treatment, and uncertainty over the inconsistent and confusing messages conveyed by the press and by women's medical advisors.

The website has between 6000 and 7000 visitors a day, and the magazine's printrun is over 13000 for a worldwide readership, though our catchment is largely the UK.

\section{WHAT DO YOU OFFER?}

Our website covers a wide spectrum of menopause-related topics, from premature menopause through symptoms such as bleeding or bladder problems; breast cancer, hysterectomy, osteoporosis; to treatments including hormone replacement therapy (HRT) and its alternatives. Our downloadable leaflets deal with many of the same topics.

The website also reviews and recommends books and products, many of which can be bought online, and provides links to other useful websites, podcasts, radio programmes and online films. Our quarterly print magazine, which can also be read free online, covers the same material as well as including regular lifestyle features and first-person stories.

Menopause Matters also gives direct support to women. The website page 'Find a Specialist' allows users to enter their postcode to locate clinics and physicians in their area, while a facility from the website offers personal e-mail advice for a fee. The website also hosts a lively peer forum where women going through the menopause offer each other advice and support.

\section{HOW DO YOU REACH YOUR USERS?}

Our website ranks highly in most search engines for the word 'menopause' and related topics; we also use social media to spread the word. The magazine is available on subscription and we also make the magazine and cards containing the website details available in GP surgeries, clinics, and even gyms and yoga studios.

We gain considerable coverage in the press and are always happy to speak to the print and broadcast media about any aspect of the menopause or its treatment, particularly HRT. We are also approached when there is adverse publicity about HRT, as there often has been since we were founded. Here, our role is to provide accurate and balanced information so that women are not unnecessarily alarmed and are then motivated to 
benefit from the most appropriate treatment where that is needed.

\section{WHAT'S BEEN YOUR BIGGEST PROBLEM?}

It has been difficult to source funding for the project. We currently rely on individual and clinic subscriptions for the magazines, on educational grants, and on advertising both in the magazine and on the website.

\section{WHAT OF THE FUTURE?}

We are launching a new-look website very soon, and we also hope to be able to provide copies of our magazines to all GP surgeries in the UK.

\section{WHAT'S BEEN YOUR BIGGEST TRIUMPH OVER THE YEARS?}

The awards we have received are very welcome. In 2004 we won the British Medical Association Patient Information Award - Website Category and in 2013 were winners of the Small Publishing Company Magazine of the Year in the Scottish Magazine Awards.

However, we rate our triumph chiefly by the messages from women, both directly and on the website forum, saying how much Menopause Matters has helped them. "I don't know how I would have coped had I not found this forum one night."

\section{HOW WOULD YOU LIKE JOURNAL READERS TO RESPOND TO THIS ARTICLE?}

Menopause Matters is aimed at the public, so do direct your patients to us so that we can deliver the information, advice and support that women need; the website is http://www.menopausematters.co.uk. Contact: Heather Currie (info@menopausematters. co.uk). If you as a professional need support, then please join the British Menopause Society (http:// www.thebms.org.uk).

Competing interests None.

Provenance and peer review Commissioned; internally peer reviewed.

Editor's note This article is one in a series of occasional articles on key health organisations worldwide. The Journal would be pleased to hear from other organisations, particularly, those based outside the UK, which would like to be similarly profiled.

\section{READERS' CONTRIBUTIONS INVITED ON 'A BETTER WAY OF WORKING'}

The Journal publishes occasional 'A Better Way of Working' articles, the purpose of which is to disseminate service delivery suggestions likely to be of interest and relevance to the Journal's readership. Readers are invited to submit suggestions based on their own personal experience for consideration by the Journal Editor. Contributions normally should not exceed 1000 words and should be written in a standardised format responding to the following four questions (or similar): Why was change needed? How did you go about implementing change? What advice would you give to others who might be considering a similar course of action? How did you show that the change had occurred? All contributions should be submitted via the Journal's online submission system at http://mc.manuscriptcentral.com/jfprhc.

\section{LETTERS TO THE EDITOR}

Letters to the Editor are welcome and generally should not exceed 600 words or cite more than five references. For comments on material published in the most recent issue of the Journal, correspondence should be received within 4 weeks of dispatch of that Journal to be in time for inclusion in the next issue. When submitting letters correspondents should include their job title(s) and their work affiliation(s)/contact address(es). A statement on competing interests should also be submitted for all letters. Letters may be submitted to the Journal Editor or to the Journal Editorial Office (details on the Editorial Board page). 